của albendazol bằng một nửa liều trẻ lớn hơn và người trưởng thành. Chúng tôi sử dụng albendazol với liều của trẻ 1 tuổi trong 3 ngày liên tiếp và thấy đáp ứng tốt với điêu trị.

\section{KẾT LUẬN}

Mất protein qua ruột do giun móc là một biến chứng nặng, ít gặp và dễ bị bỏ sót. Triệu chứng nhiễm kí sinh trùng nói chung và giun móc nói riêng thường không đặc hiệu, vì vậy bác sĩ lâm sàng cần phải có kinh nghiệm để nghĩ tới và chỉ định xét nghiệm chẩn đoán phù hợp.

\section{TÀI LIÊU THAM KHẢO}

1. Nguyễn Văn Đề (2013). Giun sán y học. Ký sinh trùng trong lâm sàng, Nhà xuất bản y học, Hà Nội, 1, 37-42.

2. Hotez P J, Brooker S, Bethony J $M$, et al (2004). "Hookworm infection". N Engl J Med, 351 (8), 799-807.
3. Gounden V, Vashisht $R$, Jialal I (2021). Hypoalbuminemia, StatPearls PublishingCopyright (C) 2021, StatPearls Publishing LLC.

4. Gupta M C, Basu A K, Tandon B N (1974). "Gastrointestinal protein loss in hookworm and roundworm infections". Am J Clin Nutr, 27 (12), 1386-1389.

5. Areekul $S$, Devakul $K$, Chantachum $Y$, et al (1971). "Gastro-intestinal protein loss in patients with hookworm infection". J Med Assoc Thai, 54 (1), 28-33.

6. Blackman V, Marsden P D, Banwell J, et al (1965). "Albmin metabolism in hookwworm anemias". Trans R Soc Trop Med Hyg, 59 472-482.

7. Crossley J R, Elliott R B (1977). "Simple method for diagnosing protein-losing enteropathies". Br Med J, 1 (6058), 428-429.

8. Florent $C_{\text {, }}$ L'Hirondel $C_{\text {, }}$ Desmazures $C_{\text {, }}$ et al (1981). "Intestinal clearance of alpha 1antitrypsin. A sensitive method for the detection of protein-losing enteropathy". Gastroenterology, 81 (4), 777-780.

\title{
TÌNH TRANG DINH DƯỠNG TRẺ 3-5 TUỔI VÀ MộT SỐ YẾU TỐ LIÊN QUAN ĐẾN SUY DINH DƯỡNG THẤP CÒI TẠI MộT SỐ XÃ, TỈNH THANH HÓA NĂM 2017
}

\section{TÓM TẮT}

Muc tiêu: Mô tả tình trang dinh dưỡng trẻ 3-5 tuổi và một số yếu tố liên quan đến suy dinh dưỡng thấp còi tại một số xã, tỉnh thanh hóa năm 2017. Phương pháp: Nghiên cứu mô tả cắt ngang trên 1522 trẻ 3- 5 tuổi tại 6 xã, tỉnh Thanh Hóa, nhằm mô tả tình trạng dinh dưỡng và một số yếu tố liên quan đến suy dinh dưỡng thấp còi của trẻ em 3-5 tuổi. Trẻ được cân, đo chiêu cao bằng phương pháp nhân trắc hợc, phỏng vấn các bà me bằng bộ câu hỏi được thiết kể sẵn. Kết quả: Kết quả nghiên cứu cho thẩy tỷ lệ suy dinh dưỡng thể nhe cân là 9,6\%; thể thấp còi là $14,5 \%$ và thể gây còm là $1,2 \%$, Thửa cân, béo phì là $2,9 \%$. Một số yếu tố liên quan đễn tình trạng suy dinh dưỡng của trẻ bao gồm cân nặng sở sinh dưới 2500gram; mẹ có trình độ học vấn dưới trung học phổ thông; số con trong gia đình từ 3 con trở lên. Kết luận: Tỷ lệ suy dinh dưỡng trẻ em 3-5 tuổi tại 6 xã, tỉnh Thanh Hóa đứng đầu là suy dinh dưỡng thể thấp còi, cân nặng sơ sinh dưới 2500 gram, mẹ có trình độ học vấn dưới trung học phổ thông, số con trong gia đỉnh từ 3 con trở lên là các yếu tố nguy cơ của bệnh này.

\footnotetext{
${ }^{1}$ Trường Đại học Y Dược Hải Phòng

2Viện Dinh dưỡng

Chịu trách nhiệm chính: Phạm Thị Thư

Email: ptthu@hpmu.edu.vn

Ngày nhận bài: 14.9.2021

Ngày phản biện khoa học: 11.11.2021

Ngày duyệt bài: 19.11.2021
}

Phạm Thị Thư ${ }^{1}$, Trương Tuyết Mai ${ }^{2}$, Nguyễn Ngọc Sáng ${ }^{2}$, Trần Thị Thu Trang ${ }^{2}$

Tư Khóa: Suy dinh dương, trẻ em, yếu tố liên quan đến suy dinh dưỡng.

\section{SUMMARY \\ NUTRITIONAL STATUS AND SOME RELATED FACTORS TO STUNTING \\ MALNUTRITION AMONG CHILDREN 3-5 \\ YEARS OLD IN SOME COMMUNES OF THANH HOA PROVINCE IN 2017}

Objectives: Describe nutritional status and some related factors to stunting malnutrition among children 3-5 years old in some communes of thanh hoa province in 2017. Method: A cross-sectional study was conducted on 1522 children 3-5 years old in six communes of Thanh Hoa province to describe nutritional status and some related factors to stunting malnutrition among children 3-5 years old. Children were measured weight, height by the anthropometric method, interviewed mothers with pre-designed questionnaires. Results: the prevalence of underweight was $9,6 \%$, stunting was $14,5 \%$ and wasting was $1,2 \%$, overweight, obese was $2,9 \%$. Some factors related to stunting malnutrition of the child including birth weight below 2500 gram; mother has an education level below high school, the number of children in the family is 3 or more. Conclusion: The prevalence of malnutrition among children 3-5 years old in 6 communes, Thanh Hoa province is ranked first by stunting, birth weight less than 2500 grams, mothers with less than high school education, 
the number of children in a family of 3 or more are risk factors for this disease.

Keywords: Malnutrition, children, related factors to malnutrition.

\section{I. ĐẶT VẤN ĐỀ}

Suy dinh dưỡng (SDD) là tình trạng bệnh lý xảy ra khi chế độ ăn nghèo protein và năng lượng, thường kèm theo tác động của nhiễm khuấn và ngược lại thường tạo điều kiện cho nhiễm khuẩn phát triển và làm cho tình trạng thiếu dinh dưỡng ngày càng nặng thêm. Năm 2011, Tổ chức Y tế Thế giới (WHO) ước tính trên toàn cầu có 115 triệu (18\%) trẻ dưới 5 tuổi nhẹ cân và 178 triệu $(28 \%)$ bị thấp còi. Một phần tư tổng số trẻ em ở các nước đang phát triển bị SDD, trong đó phần lớn sống ở châu Phi và châu Á [1]. SDD ở trẻ em dưới 5 tuổi dẫn tới không chỉ làm trẻ chậm phát triển thể chất, trí tuệ, chậm phát triển giáo dục, xã hội và kinh tế mà còn làm tăng nguy cơ tử vong và mắc bệnh do tiêu chảy và tăng nguy cơ nhiểm trùng, ước tính khoảng $35 \%$ [2]. Ớ nước ta trong những năm qua, dù đã có nhiều thành tựu trong công tác phòng chống SDD, nhưng tỷ lệ SDD ở trẻ em nước ta vẫn còn ở mức cao, đặc biệt là SDD thể thấp còi là $23,2 \%$, thể nhẹ cẩn là $12,8 \%$ (năm 2018) [3]. Thanh Hóa là nơi có tỷ lệ suy dinh dưỡng còn khá cao so với mức trung bình của cả nước. Vì vậy, nghiên cứu được tiến hành nhằm đánh giá thực trạng dinh dưỡng ở trẻ 3-5 tuổi thuộc 6 xã thuộc 2 huyện Nông Cống và Yên Định, tỉnh Thanh Hóa. Từ đó cần lựa chọn định hướng can thiệp cải thiện tình trạng dinh dưỡng cho trẻ.

\section{II. ĐỐI TƯợNG VÀ PHƯƠNG PHÁP NGHIÊN CỨU 2.1 Đối tượng nghiên cứu}

- Trẻ từ 3-5 tuổi, đi học trường mầm non và mẹ hoặc người chăm sóc chính cho trẻ

- Tiêu chuấn lựa chọn: Trẻ khỏe manh bình thường. Bà me có đủ sức khỏe, có khả nằng đọc, hiểu để trả lời các câu hỏi của điều tra viên.

- Tiêu chuẩn loại trừ: Trẻ mắc dị tật bẩm sinh, gù vẹo cột sống và các bệnh cấp tính. Bà me không có khả năng trả lời các câu hỏi phỏng vân.

\section{2 Đia điểm và thời gian nghiên cứu}

Nghiên cứu được tiến hành tại 6 xã: xã Định Thành, Yên Thái, Yên Tâm huyên Yên định và xã Vạn Thắng, Vạn Hòa, Công Chính huyện Nông Cống, tỉnh Thanh Hóa từ tháng 5/2017 đến tháng 5/2018.

2.3 Thiết kế nghiên cứu. Nghiên cứu mô tả cắt ngang.

\subsection{Cỡ mẫu nghiên cứu}

Áp dụng công thức tính cõ mẫu ước lượng tỷ lệ trong nghiên cứu mô tả:

$$
\mathrm{n}=\mathrm{Z}^{2}{ }_{1-\mathrm{a} / 2} \cdot \frac{\mathrm{p}(1-\mathrm{p})}{\mathrm{d}^{2}}
$$

Trong đó: n là cõ mẫu nghiên cứu tối thiểu; Z: hệ số tin cậy phụ thuộc vào ngưỡng xác suất a (chọn $a=0,05$ với độ tin cậy $95 \%$ thì $Z$ (1 $\mathrm{a} / 2)=1,96$ ); $\mathrm{d}$ là sai số cho phép (lấy $\mathrm{d}=$ $0,05) ; p$ là tỷ lệ trẻ dưới 5 tuổi bị SDD (lấy $p=$ 0,138 , tỷ lệ trẻ dưới 5 tuổi toàn quốc SDD thể nhe cân năm 2016 là 13,8\% [3]). Tính được cõ mẫu là 183 trẻ. Tổng số trẻ cần nghiên cứu tại 6 xã là 183 x 6 xã $=1098$ trẻ. Thực tế chúng tôi tiến hành nghiên cứu được 1522 trẻ 3-5 tuổi.

\subsection{Phương pháp chọn mẫu}

Chọn tỉnh nghiên cứu: chọn chỉ định tỉnh Thanh Hóa; huyện Yên Định và Nông Cống.

Chọn xã nghiên cứu: Chọn chỉ định 3 xã của huyện Yên Định (Định Thành, Yên Thái, Yên Tâm huyện Yển định) và 3 xã của huyện Nông Cống (Vạn Thắng, Vạn Hòa, Công Chính), là xã vùng nông thôn; nơi dân số đông, chính quyền địa phương tình nguyện hỗ trợ triển khai.

2.6 Biến số nghiên cứu. Các biến số để đánh giá tình trạng SDD của trẻ em dưới 3-5 tuổi gồm: Tháng tuổi; cân nặng sơ sinh; cân nặng hiện tại; chiều cao đứng hiện tại. Các biến số để đánh giá một số yếu tố liên quan đến tình trạng SDD chung của trẻ gồm: Cân nặng sơ sinh, trình độ của mẹ, số con trong gia đình, thời điểm cai sữa cho trẻ.

2.7. Phương pháp và công cụ thu thập số liệu, tiêu chuẩn đánh giá. Các thông tin được thu thập là họ và tên, ngày sinh, giới, địa chỉ của trẻ.

Thông tin về chỉ số nhân trắc của trẻ: cân nặng bằng cân điện tử TANITA với độ chính xác $0,1 \mathrm{~kg}$, được kiểm tra trước khi sử dụng; xác định chiêu cao sử dụng thước gỗ với độ chính xác $0,1 \mathrm{~cm}$ để đo chiều cao đứng. Kết quả được ghi là $\mathrm{cm}$ và 1 số lẻ sau dấu phẩy. Tuối của trẻ được tính bằng cách lấy ngày tháng năm điều tra trừ đi ngày tháng năm sinh của trẻ và phân loại theo WHO 2006.

Thông tin về bà mẹ: Thông tin được thu thập bằng cách phỏng vấn trực tiếp bà mẹ bằng bộ câu hỏi được thiết kế sẵn.

Đánh giá tình trạng dinh dưỡng của trẻ dưới 5 tuổi: Dựa theo chuẩn phân loại của WHO 2006, trẻ SDD thể nhẹ cân khi chỉ số cân nặng/tuối $(C N / T)<-2 S D$, SDD thể thấp còi khi chiều cao/tuổi $(C C / T)<-2 S D$, SDD thể gầy còm khi chỉ số cân nặng/chiều cao (CN/CC) <-2SD. 
Đánh giá tình trạng dinh dưỡng của trẻ em 5 tuổi: Tương tự như trẻ dưới 5 tuổi; riêng chỉ số thừa cân xác định khi Zscore $\mathrm{CN} / \mathrm{CC}>1$ và béo phì Zscore $\mathrm{CN} / \mathrm{CC}>2$

2.8. Xử lý và phân tích số liệu. Số liệu về nhân trắc học được xử lý bằng phần mềm Anthro của WHO, 2006. Sử dụng phần mềm Epi Data để nhập liệu và phần mềm SPSS 18.0 để phân tích. Test kiểm định thống kê là X2 test so sánh tỷ lệ giữa các nhóm, $\mathrm{t}$ - test so sánh giá trị trung bình giữa 2 nhóm. Giá trị $p<0,05$ được xem có ý nghĩa thống kê.

2.9. Đạo đức nghiên cứu. Nghiên cứu được thông qua Hội đồng Đạo đức, Hội đồng Khoa học - Viện Dinh dưỡng trước khi triển khai. Đối tượng nghiên cứu được cung cấp đầy đủ nội dung, mục đích nghiên cứu và đông ý tham gia nghiên cứu. Toàn bộ thông tin thu thập được quản lý bởi nghiên cứu viên, giữ bí mật và chỉ sử dụng cho mục đích nghiên cứu.

\section{KẾT QUẢ NGHIÊN CỨU}

\section{Bảng 1. Phân bố chỉ số nhân trắc của trẻ theo giới}

\begin{tabular}{|c|c|c|c|c|c|}
\hline $\begin{array}{c}\text { Chỉ số nhân } \\
\text { trắc }\end{array}$ & \multirow{2}{*}{ Tuổi } & \multicolumn{3}{|c|}{ Nam } & \multicolumn{2}{c|}{ Nũ } \\
\cline { 2 - 6 } & & $\mathbf{n}$ & TB \pm SD & n & TB \pm SD \\
\hline Tháng tuối & $3-5$ & 815 & $53,3 \pm 9,5$ & 707 & $54,1 \pm 9,6$ \\
\hline \multirow{4}{*}{ Cân nặng } & $3-5$ & 815 & $16,1 \pm 2,9^{\mathrm{a}}$ & 707 & $15,6 \pm 2,7$ \\
\cline { 2 - 6 } & 3 & 257 & $14,4 \pm 2,0^{\mathrm{b}}$ & 221 & $13,8 \pm 2,0$ \\
\cline { 2 - 6 } & 4 & 327 & $16,3 \pm 2,5^{\mathrm{b}}$ & 273 & $15,6 \pm 2,3$ \\
\cline { 2 - 6 } & 5 & 231 & $17,8 \pm 3,2$ & 213 & $17,3 \pm 2,7$ \\
\hline \multirow{4}{*}{ Chiều cao } & $3-5$ & 815 & $101,8 \pm 6,6$ & 707 & $101,3 \pm 6,9$ \\
\cline { 2 - 6 } & 3 & 257 & $95,7 \pm 4,3^{\mathrm{b}}$ & 221 & $94,8 \pm 4,7$ \\
\cline { 2 - 6 } & 4 & 327 & $102,5 \pm 4,8$ & 273 & $101,9 \pm 4,8$ \\
\cline { 2 - 6 } & 5 & 231 & $107,6 \pm 5,2$ & 213 & $107,3 \pm 5,0$ \\
\hline
\end{tabular}

* T-test khi so sánh các chỉ số giữa trẻ trai và gái: ${ }^{a} p<0,001,{ }^{b} p<0,05$

Bảng 1 cho thấy cân nặng trung bình của trẻ trai là $16,1 \pm 2,9$ kg và trẻ gái là $15,6 \pm 2,7 \mathrm{~kg}$; chiều cao trung bình của trẻ trai là $101,8 \pm 6,6 \mathrm{~cm}$ và trẻ gái là $101,3 \pm 6,9 \mathrm{~cm}$. Chỉ số cân nặng trẻ trai cao hơn trẻ gái, sự khác biệt có ý nghĩa thống kê với trẻ 3 tuổi. $p<0,05$.

Bảng 2: Phân bố trẻ theo giới, nhóm tuổi tại 6 xã, tỉnh Thanh Hóa

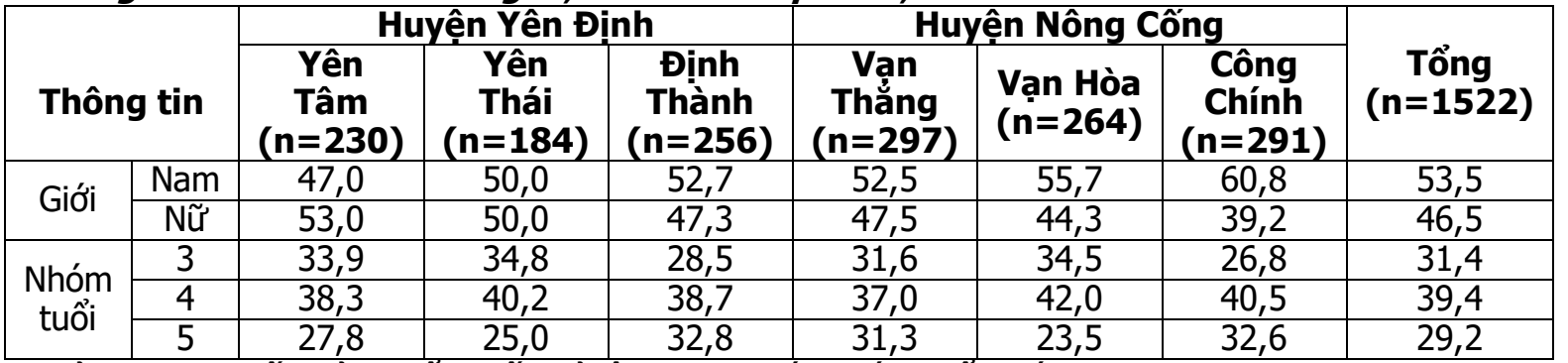

Bảng 2 cho thấy trẻ 4 tuối chiếm tỷ lệ cao hơn các nhóm tuối khác.

Bảng 3. Tình trang SDD thấp còi, nhe cân, gây còm và thừa cân, béo phì ở trẻ 3-5 tuổi ở 6 xã của tỉnh Thanh Hóa theo giới

\begin{tabular}{|c|c|c|c|c|c|c|}
\hline \multirow{2}{*}{ Thông tin } & \multicolumn{2}{|c|}{ Nam } & \multicolumn{2}{c|}{ Nữ } & \multicolumn{2}{c|}{ Tống } \\
\cline { 2 - 7 } & $\mathbf{n}$ & $\mathbf{\%}$ & $\mathbf{n}$ & $\mathbf{\%}$ & $\mathbf{n}$ & $\mathbf{\%}$ \\
\hline SDD thế nhêe cân & 70 & 8,6 & 76 & 10,7 & 146 & 9,6 \\
\hline SDD thể thẩp còi & 122 & 15,0 & 98 & 13,9 & 220 & 14,5 \\
\hline SDD thế gầy còm & 5 & 0,8 & 8 & 1,6 & 13 & 1,2 \\
\hline Thừa cân, béo phì & 28 & 3,4 & 16 & 2,3 & 44 & 2,9 \\
\hline
\end{tabular}

Bảng 3 cho thây Tỷ lệ SDD thể the cân ở trẻ trai là $8,6 \%$, ở trẻ gái là $10,7 \%$. Tỷ lệ SDD thể thấp còi ở trẻ trai là $15,0 \%$, ở trẻ gái $13,9 \%$ Tỷ lệ SDD thể gầy còm ở trẻ trai là $0,8 \%$, ở trẻ gái là $1,6 \%$; tỷ lệ thừa cân ở trẻ trai là $3,4 \%$, ở trẻ gái là 2,3\%. Sự khác biệt không có ý nghĩa thống kê khi so sánh tỷ lệ SDD thể nhẹ cân, thấp còi, gâyy

còm, thừa cân béo phì giữa trẻ trai và trẻ gái.

Hình 1 cho thấy tỷ lệ SDD nhẹ cân cao nhất ở trẻ 3-5 tuổi thuộc xã Công Chính (14,1\%) tiếp theo là xã Định Thành $(11,3 \%)$ và xã Yên Thái $(9,8 \%)$, Vạn Thắng $(8,8 \%)$, Vạn Hòa $(6,8 \%)$, thấp nhất là xã Yên Tâm $(6,1 \%)$. 


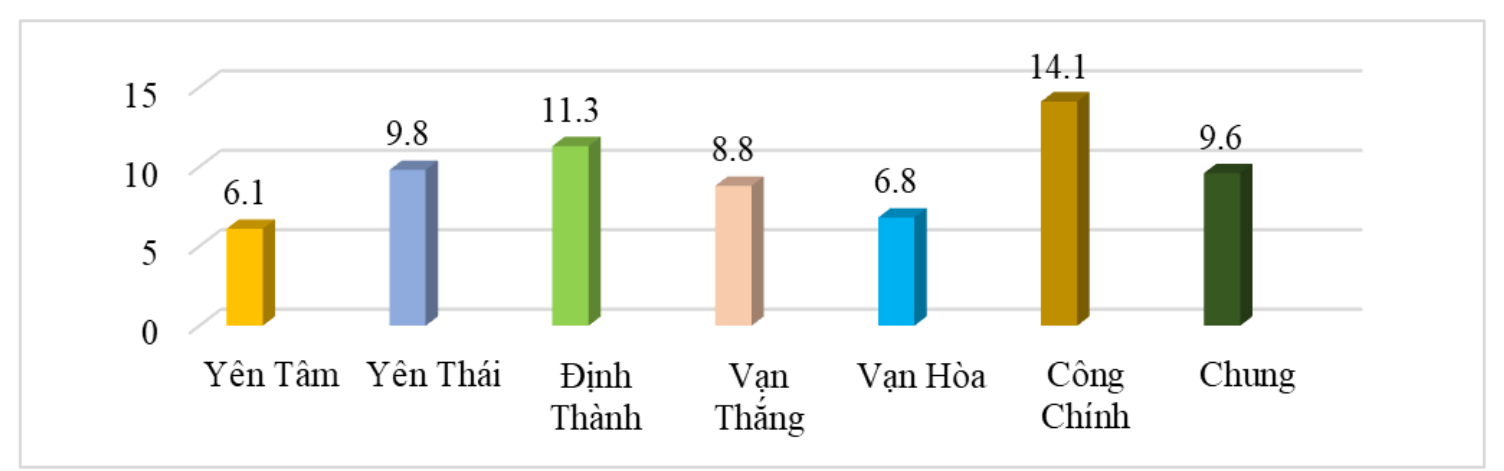

Hình 1. Tỷ lệ suy dinh dưỡng nhẹ cân ở trẻ 3 - 5 tuổi tại 6 xã, tỉnh Thanh Hóa

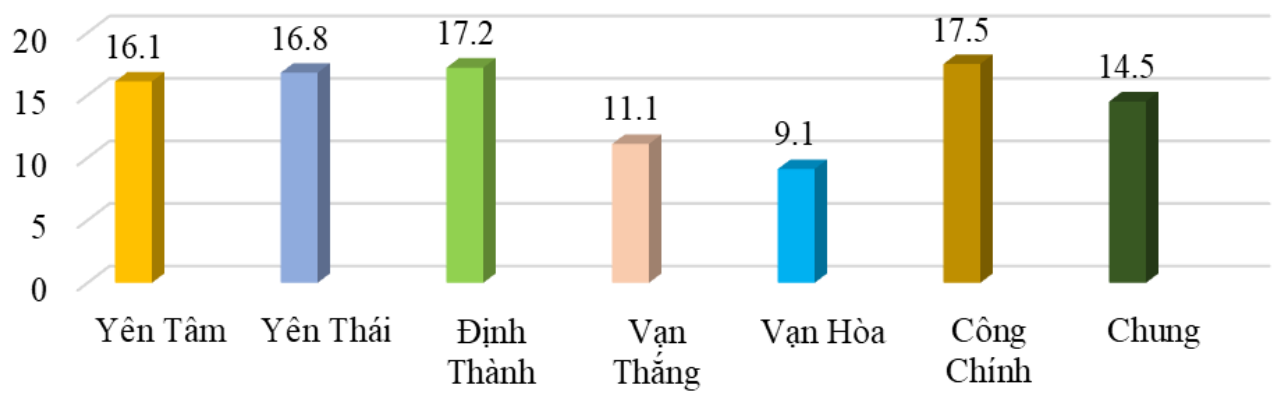

Hình 2. Tỷ lê suy dinh dưỡng thấp còi ở trẻ 3 - 5 tháng tuổi tại 6 xã, tỉnh Thanh Hóa

Hình 2 cho thấy tỷ lệ SDD thấp còi cao nhất ở trẻ 3-5 tuổi thuộc xã Công Chính (17,5\%) tiếp theo là xã Định Thành $(17,2 \%)$ và xã Yên Thái $(16,8 \%)$, Yên Tâm $(16,1 \%)$, Vạn Thắng $(11,1 \%)$, thấp nhất là xã Vạn Hòa $(9,1 \%)$.

Bảng 4. Một số yếu tố liên quan đến tình trạng suy dinh dưỡng thấp còi của trẻ

\begin{tabular}{|c|c|c|c|c|}
\hline Yếu tố liên quan & Chì số & OR & $95 \%$ CI & $\mathbf{p}$ \\
\hline Cân nặng sơ sinh & $\begin{array}{c}\text { Thấp }(<2500 \mathrm{~g}) \\
\text { Đủ }\end{array}$ & 1,88 & $1,09-3,25$ & $<0,05$ \\
\hline Thời điểm cai sữa & $\begin{array}{l}<18 \text { tháng } \\
\geq 18 \text { tháng }\end{array}$ & 1,23 & $0,89-1,69$ & $>0,05$ \\
\hline $\begin{array}{c}\text { Số con trong gia } \\
\text { đình }\end{array}$ & $\begin{array}{l}\geq 3 \text { con } \\
1-2 \text { con }\end{array}$ & 1,66 & $1,18-2,32$ & $<0,05$ \\
\hline $\begin{array}{l}\text { Trình đô hô học vấn } \\
\text { cúa bà mẹ }\end{array}$ & $\begin{array}{l}<\text { Trung học phố thông } \\
\geq \text { Trung học phố thông }\end{array}$ & 1,37 & $1,01-1,84$ & $<0,05$ \\
\hline
\end{tabular}

Bảng 4 cho thấy trẻ em có cân nặng sơ sinh thấp hơn $2500 \mathrm{~g}$ có nguy cơ mắc suy dinh dưỡng thấp còi cao hơn gấp 1,8 lần so với trẻ khác, sự khác biệt này có ý nghĩa thống kê với $p<0,05$. Trẻ cai sữa dưới 18 tháng tuổi có nguy cơ bị SDD cao gấp 1,2 lần so với trẻ được bú sữa mẹ đến $\geq$ 18 tháng. Tuy nhiên sự khác biệt không có ý nghĩa thống kê với $p>0,05$. Gia đình có tữ 3 con trở lên, trẻ có nguy cơ SDD cao gấp 1,6 lần gia đình có từ $1-2$ con, sự khác biệt này có ý nghĩa thống kê với $p<0,05$. Mẹ có trình độ học vấn dưới THPT, trẻ có nguy cơ bị SDD cao gấp 1,3 lần so với trẻ me có trình độ học vấn từ THPT trở lên sự khác biệt này có ý nghĩa thống kê với $p<0,05$.

\section{BÀN LUÂN}

Điều tra 1522 trẻ 3-5 tuổi, đi học tại các trường mầm non, thuộc huyện Yên Định và Nông Cống tỉnh Thanh Hóa cho thấy, cân nặng trung bình của trẻ trai là $16,1 \pm 2,9 \mathrm{~kg}$ và trẻ gái là $15.6 \pm 2.7 \mathrm{~kg}$. Kết quả nghiên cứu của chúng tôi cao hơn so với kết quả nghiên cứu của Nguyễn Song Tú và cộng sự tiến hành nghiên cứu tình trạng dinh dướng cũng trên trẻ 36-71 tháng tuổi tại Yên Bái (cân nặng trung bình của trẻ trai là $15,3 \pm 2,6 \mathrm{~kg}$, trẻ gái là $14,5 \pm 2,3 \mathrm{~kg}$ ) [4]. Điều này có thể được giải thích Yên Bái là tỉnh miền núi phía bắc, điều kiện kinh tế của người dân khó khăn hơn nên tỷ lệ trẻ suy dinh dưỡng cao 
hơn Thanh Hóa. Chiều cao trung bình của trẻ trai là $101,8 \pm 6,6 \mathrm{~cm}$ và trẻ gái là $101,3 \pm 6,9 \mathrm{~cm}$. Kết quả nghiên cứu của chúng tôi cũng cao hơn hơn so với kết quả nghiên cứu của Nguyễn Song Tú và cộng sự tiến hành nghiên cứu tình trạng dinh dưỡng cũng trên trẻ 36-71 tháng tuổi tại Yên Bái (chiêu cao trung bình của trẻ trai là $100,5 \pm 6,8$ $\mathrm{cm}$, trẻ gái là $99,2 \pm 6,3 \mathrm{~cm}$ ) [4].

Tỷ lệ SDD nhẹ cân chung trẻ 3-5 tuổi là 9,6\%. Trong đó cao nhất thuộc xã Công Chính $(14,1 \%)$ tiếp theo là xã Định Thành $(11,3 \%)$ và xã Yên Thái $(9,8 \%)$, Vạn Thắng $(8,8 \%)$, Vạn Hòa $(6,8 \%)$, thấp nhất là xã Yên Tâm $(6,1 \%)$. Kết quả nghiên cứu của chúng tôi thấp hơn so với kết quả nghiên cứu của Trần Quang Trung tại huyện $B a$ Vì, thành phố Hà Nội $(9,1 \%)$ [5] và kểt quả nghiên cứu của Hoàng Thị Hoa Lê $(12,2 \%)$ [6]. Tỷ lệ suy dinh dưỡng thấp còi chung trẻ 3-5 tuổi là $14,5 \%$. Trong đó, tỷ lệ SDD thấp còi cao nhất ở trẻ 3-5 tuổi thuộc xã Công Chính (17,5\%) tiếp theo là xã Định Thành $(17,2 \%)$ và xã Yên Thái $(16,8 \%)$, Yển Tâm $(16,1 \%)$, Vạn Thắng $(11,1 \%)$, thấp nhất là xã Vạn Hòa $(9,1 \%)$. Kết quả nghiên cứu của chúng tôi thấp hơn so với kết quả nghiên cứu của Trân Quang Trung tại huyện $\mathrm{Ba}$ Vì, thành phố Hà Nội $(14,9 \%)$ [5] và kết quả nghiên cứu của Hoàng Thị Hoa Lê $(18,5 \%)[6]$. Điều này có thể được giải thích, nghiên cứu đánh giá tình trạng dinh dưỡng trên trẻ 3-5 tuổi nên tỷ lệ suy dinh dương nhe cân và thấp còi thấp hơn các tác giả trên nghiên cứu trên trẻ dưới 5 tuổi, bao gồm trẻ dưới 36 tháng tuổi và nhóm tuổi này có tỷ lệ suy dinh dưỡng cao hơn nhóm trẻ từ 36 tháng tuổi trở lên.

Nghiên cứu chỉ ra, cân nặng sơ sinh thấp có mối liên quan chặt chẽ với nguy cơ mắc SDD. Trẻ em có cân nặng sơ sinh thấp hơn $2500 \mathrm{~g}$ có nguy cơ mắc suy dinh dưỡng thấp còi cao hơn gấp 1,8 lần so với trẻ khác. CNSS thấp có thể là do dinh dương của người me kém trong thời kỳ mang thai. Giai đoạn này, đứa trẻ hoàn toàn phụ thuộc vào me về dinh dưỡng thông qua nhau thai nên bất kỳ sự thiếu hụt dinh dưỡng nào của người mẹ sẽ ảnh hưởng xấu đến sự tăng trưởng và phát triển của trẻ. Sự khác biệt này có ý nghĩa thống kê với $p<0,05$. Kết quả này tương tự với kết quả nghiên cứu của các tác giả Hoàng Thị Hoa Lê và các cộng sự tại xã Quyết Tiến, Tiển Lãng, Hải Phòng năm 2019 cũng chỉ ra rằng trẻ có cân nặng sơ sinh dưới $2500 \mathrm{gram}$ có nguy cơ SDD cao gấp 4,0 lần so với trẻ có cân nặng sơ sinh trên 2500gram [6] và Trần Quang Trung và cộng sự tiến hành nghiên cứu tại huyện Ba Vì, thành phố Hà Nội (3,9 lần) [5]. Theo khuyến cáo của WHO, thời gian cai sữa mẹ cho trẻ nên ở trong khoảng từ 18 đến 24 tháng. Do đó, song song với việc cho trẻ ăn bổ sung thì người mẹ nên tiếp tục cho trẻ bú cho đến khi trẻ tròn 24 tháng tuổi [7]. Kết quả của chúng tôi cho thấy trẻ cai sữa dưới 18 tháng tuổi có nguy cơ bị SDD cao gấp 2,56 lần so với trẻ được bú sữa mẹ đến $\geq 18$ tháng. Tuy nhiên sự khác biệt không có ý nghĩa thống kê với $p>0,05$. Gia đình có từ 3 con trở lên, trẻ có nguy cơ SDD cao gấp 1,6 lần gia đình có từ $1-2$ con, sự khác biệt này có ý nghĩa thống kê với $p<0,05$. Me có trình độ học vấn dưới THPT, trẻ có nguy cớ bị SDD cao gẩp 1,3 lần so với trẻ me có trình độ học vấn từ THPT trở lên sự khác biệt này có ý nghĩa thống kê với $p<0,05$. Kết quả nghiên cứu của chúng tôi phù hợp với kết quả nghiên cứu của Hoàng Thị Hoa Lề [6].

\section{KẾT LUÂ̂N}

Nghiên cứu mô tả cắt ngang trên 1522 trẻ 35 tuổi, đi học tại các trường mầm non thuộc huyện Yên Định và Nông Cống tỉnh Thanh Hóa. Kết quả nghiền cứu cho thấy:

Tỷ lệ suy dinh dưỡng thể thấp còi là $14,5 \%$; suy dinh dưỡng thể nhẹ cân là $9,6 \%$; suy dinh dưỡng thể gầy còm là $1,2 \%$. Yếu tố liên quan đến suy dinh dưỡng thấp còi của trẻ gồm: Cân nặng sơ sinh dưới $2500 \mathrm{gram}$, mẹ có trình độ học vấn dưới Trung học phổ thông, gia đình có từ 3 con trở lên. Cần có biện pháp can thiệp phù hợp để cải thiện tình trạng dinh dưỡng của trẻ em tại xã Yên Tầm, Yên Thái, Định Thành, huyện Yên Định và xã Vạn Thắng, Vạn Hòa, Công Chính huyện Nông Cống, tỉnh Thanh Hóa.

\section{TÀI LIỆU THAM KHẢO}

1. Organization, W.H., (2011). World Health Statistics 2011. Geneva, Switzerland: WHO Department of Health Statistics and Informatics.

2. Black, R.E., Allen, L.H., Bhutta, Z.A., et al., (2008). Maternal and child undernutrition: global and regional exposures and health consequences. The lancet. 371(9608): p. 243-260.

3. Viện Dinh dưỡng (2020). Thống kê về tình trạng dinh dưỡng của trẻ em qua các năm.

4. Nguyê̂n Song Tú, Nguyễn Thị Lâm, Đoàn Thị Ánh Tuyết và CS (2019). Tình trang dinh dướng trẻ 36-71 tháng tuổi tại các trường mâm non huyện Lục Yên và Yên Bỉnh, tỉnh Yên Bái, 2017. Tạp chí Ý học Dự phòng. 29(2).

5. Trân Quang Trung, Nguyền Thị Thùy Linh, Lê Thị Hiên và CS (2020). Tình trạng dinh dưỡng và một số yếu tố liên quan ở trẻ em dưới 5 tuổi tại huyện Ba Vì thành phố Hà Nội năm 2019. Tạp chí $Y$ hoc Dự phòng, 2020. 30(5): p. 82-89.

6. Hoàng Thị Hoa Lê, Hoàng Thị Vân Anh, Cáp Minh Đức (2021). Tình trạng sưy dinh dướng và 
một số yễu tố liên quan ở trẻ em dưới 5 tuổi tại xã Quyết Tiến, Tiên Lãng, Hải Phòng năm 2019 2020. Tạp chí Y học Dự phòng. 31(5).
7. Victora, C.G., de Onis, M., Hallal, P.C., et al.,(2010). Global database on child growth and malnutrition. Pediatrics. 125: p. e473-e480.

\section{VAI TRÒ CỦA FIBRINMONOMER HÒA TAN TRONG CHẨN ĐOÁN ĐÔNG MÁU Nô̂I QUẢN RẢI RÁC Ở BÊNH NHÂN SỐC NHIỄM KHUẨN TẠI TRUNG TÂM CẤP CỨU A9 BÊ̂NH VIÊ̂N BẠCH MAI}

\section{TÓM TẮT}

Mục tiêu: Mô tả sơ bộ tình trạng đông máu nội quản rải rác trên bệnh nhẩn sốc nhiễm khuẩn. Đánh giá vai trò của fibrinmonomer hòa tan trong chẩn đoán đông máu nội quản rải rác trên bệnh nhân sốc nhiếm khuẩn thu thâp được tai trung tâm cấp cứu A9 bệnh viên Bach Mai trong thời gian từ tháng 6 năm 2020 đển tháng 4 năm 2021. Đối tượng và phương pháp nghiên cứu: 61 bệnh nhân được lấy theo phương pháp chọn mẫu thuận tiện,đáp ứng tiêu chuẩn lựa chọn và không có tiêu chuẩn loại trừ, nghiên cứu sử dung thang điểm chẩn đoán đông máu nội quản rải rác(DIC) của ISTH 2001, tiêu chuẩn chẩn đoán sốc nhiễm khuẩn theo Sepsis-3. Kết quả: 61 bệnh nhân sốc nhiễm khuẩn được lấy vào nghiên cứu có đô tuổi trung bình $59.95 \pm 12.23$, nam giới chiếm $73.8 \%$. Nguyên nhân hàng đầu là từ hô hấp đến ổ bung, tiết niêu. Có 34 bênh nhân được chẩn đoán DIC toàn thể chiểm $55.8 \%$. Fibrinmonomer có vai trò trong chẩn đoán DIC với diện tích dưới đường cong ROC, độ đặc hiệu, giá trị dự báo âm tính, giá trị dự báo dương tính cao hơn D-Dimer.

Tư khóa: sốc nhiếm khuẩn, đông máu nội quản rải rác, DIC, fibrin monomer hòa tan, D-dimer, bệnh viện Bạch Mai.

\section{SUMMARY \\ VALUE OF SOLUBE FIBRINMONOMER IN DIAGNOSIS THE DISSEMINATE INTRAVASCULAR COAGULATION IN SEPTIC SHOCK PATIENTS IN CENTER OF EMERGENCY MEDICINE A9, BACHMAI HOSPITAL}

Purpose: Describe characteristics of disseminated intravascular coagulation in patients with septic shock. Evaluation of the role of soluble fibrinmonomer in the diagnosis of disseminated intravascular coagulation in septic shock patients admitted in center of emergency medicine A9, Bach Mai hospital from June 2020 to April 2021. Subjects and methods: 61 patients included. Our study use ISTH 2001 criteria for disseminated intravascular coagulation and Sepsis-3 criteria for septic shock. Results: Mean age is $59.95 \pm$

${ }^{1}$ Trường Đại hoc Y Hà Nọi

${ }^{2}$ Trung tâm cấp cứu A9, Bệnh viện Bạch Mai Chịu trách nhiệm chính: Nguyễn Thị Minh Phương Email: Nguyenminhphuong.yhn@gmail.com Ngày nhận bài: 15.9.2021

Ngày phản biên khoa hoc: 12.11.2021

Ngày duyệt bài: 22.11.2021 12.23 , male $73.8 \%$. The most frequent source is respiratory infection, followed by abdominal and urinary ones, respectively. Overt DIC observed in 34 patients, $55.8 \%$. Compare to D-dimer in diagnosis DIC, AUC of ROC curve, specificity, positive predictive value, negative predictive value of fibrin monomer is higher.

Keywords: septic shock. disseminated intravascular coagulation, DIC, solube fibrinmonomer, D-dimer.

\section{I. ĐăT VẤN ĐỀ}

Sốc nhiễm khuẩn (SNK) là một bệnh lý nặng, xảy ra ở 10-20 \% BN ICU với tỉ lệ tử vong cao $\geq$ $40 \%$ [1]. SNK gây ra hoạt hóa quá trình viêm và hê thống đông cầm máu, dẫn tới các bất thường vi mạch, rối loạn chức năng đa cơ quan, trong đó DIC là một rối loạn thường gặp và nghiêm trong [1]. DIC là hậu quả đồng thời là yếu tố thúc đây,làm nặng thêm tình trạng bênhh,sự phát triển của DIC ở bệnh nhân SNK đã được xác nhận là một yếu tố độc lập tiên lượng tử vong. Kết quả điều trị phụ thuộc vào kiểm soát nhiễm khuẩn, đảm bảo huyết động và điêu chỉnh các rối loạn chức năng bao gồm rối loạn chức năng hệ thống đông máu. Do đó việc chẩn đoán sớm và điêu trị DIC có vai trò quan trọng. Trong bệnh cảnh của sốc nhiễm khuẩn, rối loạn quá trình đông máu do nhiều nguyên nhân như suy các tạng khác như suy gan; giảm tiểu câu do vì khuẩn ức chế tủy xương, do điều trị (heparin, thuốc kháng sinh...), fibrinogen tăng như là một marker viêm; làm giảm độ đặc hiệu của các xét nghiệm đông câm máu. Điều này đặt ra yêu câu cần có một chỉ điểm đủ nhạy, đặc hiệu, tiện lợi trong tính toán, chẩn đoán DIC. Bên cạnh DDimer là xét nghiệm được dùng phổ biển hiện tại, Fibrinmonomer hòa tan(sFM) gân đây cũng được dùng như là một chỉ số cho chẩn đoán DIC với độ nhạy độ đặc hiệu cao, khả năng chẩn đoán sớm [2].

Vì vậy chúng tôi tiến hành nghiên cứu với mục tiêu đánh giá: "Mô tả sơ bộ tình trạng đông máu nội quản và vai trò của xét nghiệm fibrinmonomer hòa tan (SFM) trong chân đoán DIC trên bệnh nhân sốc nhiễm khuẩn". 